\title{
Elderly consumers and financial choices: A systematic review
}

\author{
Gianluigi Guido ${ }^{1} \cdot$ Cesare Amatulli ${ }^{2}$. Andrea Sestino
}

Received: 4 December 2018 / Revised: 30 August 2020 / Accepted: 6 October 2020 / Published online: 3 November 2020 (c) The Author(s) 2020

\begin{abstract}
The purpose of this paper is to investigate elderly choices and behaviors in financial services markets. A systematic review of a five-decade period (1970-2019) of academic research in the marketing field was carried out in order to identify elderly consumers' decisions regarding financial asset management and legacy, highlighting the main findings of extant research and practical implications for marketers. Results shed light on financial asset management in terms of welfare, retirement planning, and investments for old age, as well as legacy practices in terms of special possessions, charities, and rites of passage. The study underlines the need to consider the heterogeneous nature of elderly consumers' values and lifestyles in designing strategies for financial services and products, emphasizing that demographic differences alone are not adequate to effectively define market segments. Furthermore, the role of mixed marketing approaches considering elderly choices are discussed, together with implications for companies that want to target such consumer target.
\end{abstract}

Keywords Elderly consumers · Financial assets management · Financial choices · Financial services · Legacy · Older consumers

\section{Introduction}

Researchers have come to define our current demographic scenario as a "grey tsunami" (Barusch 2013): an increasingly ageing population resulting from greater life expectancy, wellness, and scientific progress. According to the World Health Organization (2018), the number of individuals aged 60 years and older is expected to reach 2 billion worldwide by 2050 . In several countries, people aged 65 and older currently represent a quarter of the total population (Mather et al. 2019). Bucking old stereotypes that describe them as sick, inactive and disinclined to spend (Weinswig

Gianluigi Guido

gianluigi.guido@unisalento.it

Cesare Amatulli

cesare.amatulli@uniba.it

Andrea Sestino

andrea.sestino@uniba.it

1 Department of Management and Economics, University of Salento, Campus Ecotekne Pal. C, Via per Monteroni, S.P.6, 73047 Lecce, Italy

2 Ionian Department in Mediterranean Law and Economic System, University of Bari Aldo Moro, Via Duomo 259, 74132 Taranto, Italy
2016), elderly consumers have come to represent one of the most important challenges for financial marketing services (Lee et al. 2019; Xiao et al. 2015). Older people usually control a large part of families' financial stock and hold higher purchasing power; as such, they significantly contribute to consumption (Asebedo et al. 2019a, b). Some studies show that in 2010 the US Baby Boomers population had an average chance of spending per capita of $\$ 54.170$ for a total of 2 trillion dollars (e.g. Ferguson and Brohaugh 2010). Moreover, the study carried out by the AT Kearney Company (2010) emphasizing that global consumers aged 60 or older spent 8 trillion dollars on goods and services with a projection to $\$ 15$ trillion total spending by 2020 , has been largely confirmed. Interestingly, considering the USA, the "silver market" controls about $70 \%$ of the US household wealth (Weinswig 2016). Therefore, it is crucial to understand how this segment makes decisions towards acquired assets. For the elderly who are retired or close to retirement, these choices represent the management of their financial assets: the level of savings and type of investments needed to fund their old age, as well as the crucial choices related to the generational change of those assets (e.g. charitable donations, bequests or philanthropic initiatives). Additionally, issues regarding financial consumption (such as debts assumption) are very controversial. Indeed, for elderly 
consumers, lower levels of debt assumption usually indicate greater financial security, especially because they probably enjoy the fixed income. As revealed by a study among American older consumers conducted by The Pew (2015), among those individuals who still work, if compared to their unoccupied peers with less income and wealth, those with higher incomes are usually more prone to assume debts and show overall healthier family balance. Moreover, about the role of age, individuals over the age of 50 have little knowledge about financial instruments and only a small part of such individuals tries to devise a retirement plan or believes to have successfully committed retirement planning (Lusardi and Mitchell 2011). Despite scholarly interest in elderly consumers, few studies have focused on their behaviour in the context of financial decisions except for those studies concerning active ageing and cognitive capabilities (Gamble et al. 2015) that underlined how cognitive changes, when associated with ageing, may influence the financial decisionmaking capabilities of the elderly. Thus, the present paper aims to fill this gap by qualitatively assessing the relationship between older people and their decisions towards their assets. The article is organized as follows: The first section describes our research methodology. The second section discusses the relevant literature on elderly consumers' decisions and the potential related marketing strategies, regarding financial asset management and legacy, highlighting the main findings of extant research and practical implications for marketers. The last section offers some conclusions and underlines the limitations of this research.

\section{Methodology}

To provide a critical review of academic (experimental and review) studies, we examined scholarly articles published in international peer-reviewed journals from January 1970 to December 2019. Specifically, we looked for articles exploring older consumers' disposition decisions towards acquired assets. According to Guido (2006), we began our search by defining a list of 14 keywords (aged, ageing, baby boomer, elder, gerontology, grey consumer, mature consumer, old age, older consumer, retired, retirement, senior consumer, senior citizen, seniority) that commonly recur in scholarly articles on elderly consumers published in the most important management journals. We then searched the three main business databases (Business Source Premiere and EconLit, hosted by EBSCO; and ABI/INFORM Complete from ProQuest) for articles published in the appropriate journals that contained the words "marketing", "consumer", or "advertising" in their title. To strengthen our research, we also considered other relevant journals that cover research areas related to marketing and elderly consumption: All the journals were English or American, thus including studies conducted in Western countries. We reviewed all these articles and synthesized the results in a coherent and integrated manner (Bal and Nijkamp 2001): For each article, we aimed to describe the adopted segmentation criterion and the main topic investigated. After identifying the target articles, we thoroughly read each one to verify its consistency with the research objectives; we also manually reviewed their bibliographies to find other relevant articles. Ultimately, this process shed light on financial assets management in terms of welfare, retirement planning, and investments for old age,

Table 1 Insights from literature towards Elderly dispositions: financial assets and legacy management

\begin{tabular}{|c|c|c|}
\hline \multirow[t]{3}{*}{ Financial assets management } & Welfare & $\begin{array}{l}\text { Financial problems } \\
\text { Social security protection } \\
\text { Insolvency of families }\end{array}$ \\
\hline & Retirement planning & $\begin{array}{l}\text { Saving behaviours } \\
\text { Elderly savers' characteristics } \\
\text { Separate beliefs towards Elderly from their real behaviours }\end{array}$ \\
\hline & Investments for the Elderly segment & $\begin{array}{l}\text { Attitudes towards dedicated financial products } \\
\text { Investment plans } \\
\text { Financial marketing strategies }\end{array}$ \\
\hline \multirow[t]{3}{*}{ Legacy management } & Special possessions & $\begin{array}{l}\text { Family inalienability } \\
\text { Possessions } \\
\text { Transfer practices and peculiarities }\end{array}$ \\
\hline & Charities & $\begin{array}{l}\text { Donations } \\
\text { Hereditary legacies } \\
\text { Philanthropic and social entrepreneurial initiatives }\end{array}$ \\
\hline & Rites of passage & $\begin{array}{l}\text { Intergenerational transfers } \\
\text { Relationship with death } \\
\text { Elderly's identity over time preservation }\end{array}$ \\
\hline
\end{tabular}


as well as legacy practices in terms of special possessions, charities, and rites of passage as shown in Table 1.

\section{Financial assets management}

\section{Welfare}

The financial status of the elderly has changed over time. Historically, elderly consumers were considered the most vulnerable social group in society-both physically and economically - and thus deserving of government protection (deserving poors). With the advancement of the Baby Boom generation, their condition significantly improved in terms of expectancies and quality of life. Nonetheless, a large share of the elderly population still has an income close to the poverty baseline. Even in wealthy economies (Masud et al. 2008), the elderly need a regulatory system that bolsters their welfare through adequate social support, based on the principle of substantial equality for all citizens. Indeed, their financial status is mainly burdened by medical expenses (health insurance, medicines, health services), which impose the greatest economic difficulty on the poorest income groups (Sharpe et al. 2001). Kim and Lyons (2008) found that health issues cause significant "financial strain", especially in terms of solvency and asset structure rather than liquidity. Chronic diseases are the main burden, especially in individuals who are not covered by insurance, as they require continuous assistance and a growing amount of medical prescriptions (Phillips et al. 1994).

Despite the expansion of the elderly population, there has been a decrease in allocated public funds for social security protection (social allowances and pensions) worldwide, especially after the latest financial crises (Oehler and Werner 2008). One solution could be to encourage citizens to vehicle their savings in pension funds with Insurance Agencies and Private Credit Institutions. However, few individuals pursue these investments, preferring instead to spend their money on useful goods in the immediate future (Rickwood and White 2009), as they often consider pension to be distant in time or a government responsibility. According to Wiener and Doescher (2008), in several countries, retirement is no longer a recognized right; thus, it is necessary for governments to use structural or communication approaches to sensitize citizens to savings for pension purposes. Structural approaches attempt to change the circumstances in which individuals save, such as the financial conditions associated with pension savings (e.g. by increasing tax benefits or raising the contribution limits of pension plans). Communicative approaches change workers' perceptions, whether through education (training subjects on the fundamentals of investment activity) or through persuasion (creating regulatory pressure). Particularly, persuasive communication can promote virtuous retirement behaviour by acting on factors that curb procrastination and stimulate the intention to save. There are four factors to consider: individuals' perception towards their savings capacity; the perceived benefits associated with savings; the perceived concerns towards the future; and the costs associated with saving activities. While there are several techniques for reaching these goals, they all largely emphasize positivity and advantages rather than fears about the future. Despite government assistance for families with unemployed members or insufficient pensions, many families have experienced insolvency (DeVaney and Hanna 1994). Householders' age, together with income and marital status, is significantly related to families' fails, as an index of less probability of insolvency. The elderly who avoid insolvency often enjoy the following factors (Tynan and Drayton 1988): assets and savings accumulated during life; the absence of long-term loans and mortgages; the absence of children to raise; and benefits derived from one's personal situation (tax exemptions, retirement income, social security checks, discounts on food, transport, and prescription drugs). Furthermore, individuals who live alone could more often be damaged by financial strain in terms of perceived economic difficulties, due to physical and economic limitations (Lee 1994). Therefore, families are a means of absorbing the blows of "bad luck" and strengthening financial knowledge. The family also plays the role of "socialization agent", changing individuals' perception of their financial condition and especially influencing the younger members (Hira 1997). Retirement planning could mitigate future disadvantages.

\section{Retirement planning}

Saving (in terms of accumulation and wealth level) is relevant for two basic reasons. Firstly, in a purely macroeconomic sense, it represents an indicator of possible future investments; secondly, it is a strong predictor of families' wellness, given the relationships between family members' ages and the propensity to save. Theories about individuals' tendency to save money during their younger working years and then increase their consumption when elderly-according to a sort of "life cycle"-have not found empirical evidence (Mullis and Metzen 1986). This is because individuals demonstrate an overall greater wellness during retirement, as well as the same savings accumulation rate over the years. Furthermore, the levels of wealth, savings and perceived wellness are lower for those families that have been affected by divorces, children to raise, poor schooling and poor health (Bearden and Wilder 2007). Disease emergencies could lead to expenses that outpace elderly consumers' expectations, cause an accelerated reduction of their saved resources. Consequently, individuals could be compelled to continue working even after retirement age (Hogarth 1987). Recent 
studies have investigated the characteristics of those who are most likely to save because of their retirement, considering variables such as age, gender, economic situation, and their intention to plan. Gough and Sozou (2005) identified six groups of savers, with age being the most influential variable in people's propensity to allocate resources for retirement. Older people are more likely to invest in pension funds because they are more aware of the proximity to this important milestone. Sex is also an important variable in this regard (Grace et al. 2010): Women are more careful than men in their investment alternatives, being aware that their living conditions will worsen in old age, that they received fewer resources when younger, and that they will have scarce social protections. According to Hemmasi et al. (1992), the individuals most prone to risk are those who are younger, have a higher level of education, face more distant pension horizons, have greater earnings and job security, greater tolerance for losses, and greater obligations towards their employees. Additionally, mature individuals are less inclined to take risks with their retirement resources, preferring to save rather than invest (Goldstein et al. 2008). According to Bateman et al. (2010), elderly individuals prefer to minimize risk rather than gamble on the growth of possible investment initiatives. However, when comparing real international data to the projections on investment behaviour, it becomes clear that the elderly have a nuanced response to financial risks (Lindbergh et al. 2008): Initial tendencies towards savings and accumulation often evolve into a slightly more riskprone attitude.

In managing their finances during retirement, the elderly show behaviour that deviates from the stereotypical image: They engage in higher consumption, invest more savings into easily liquidated financial products (rather than fixed assets), and provide financial assistance to other family members (i.e. aiding younger generations and not vice versa) (Chevalier 2003). The demographic change that arose with the Baby Boomers (people born in $50 \mathrm{~s}$ ) overcomes general convictions towards elderly financial planning taken as the basis for the marketing activities of the companies in the financial sector (Coughlin and D'ambrosio 2009). In order to improve planners' ability to respond to consumers' needs, Coughlin and D'ambrosio (2009) focused on seven faulty assumptions: the belief that men are the main consumers of these services (probably because they are imagined as the primary income earners) without adequately assessing women's contributions; the belief that only finance motivates investment choices, while ignoring the impact of people's hopes and fears; the belief that planning is a rational and desired activity, even though its performance involves certain emotions, commitments and sacrifice; the belief that only the brand is important, without considering that loyalty arises from brand trustworthiness, which is determined by constant innovation and obtained results; the belief that the elderly are looking for a wide range of information when planning, when they are really looking for quality and thus depend on the suggestions and reliability of the consultant; the belief that financial planning is a simplistic individual choice, even though it may involve the whole family and could potentially affect different stakeholders; and finally, the belief that consumers who plan their retirement are only interested in "numbers", even though they may want to juggle old age with related future issues (Hauff 2014), such as long-term treatments or even new career or business opportunities.

\section{Investments for the elderly segment}

Because of the heterogeneity of the elderly segment in terms of economic availability and risk propensity, dedicated financial products need to be differentiated (Philp et al. 1992) based on elderly consumers' demonstrated attitudes: whether these products are perceived as facilitations or as discriminations. Analysing elderly preferences for specific financial products, Dunne and Turley (1997) found that such consumers hold a positive attitude towards most of them, with a particular preference for free programs; however, they also exhibited a widespread lack of awareness about the initiatives reserved for them, which was only partially moderated by the level of education. For elderly consumers with a lower cognitive age, dedicated financial products appeared to be deceptive. When investigating bank accounts and Equity Release Products (ERPs), Brennan and Ritch (2010) observed that the elderly lost faith in these products and suppliers due to the banks' excessive profit and lack of adequate consumer service, alongside additional constraints (e.g. limited access to alternative forms of long-term mortgage do to their age). Using Moschis' (1996) hierarchical segmentation model to describe elderly preferences for using their financial resources, Moschis and Burkhalter (2007) did not find particular differences between groups. In fact, elderly consumers exhibited a widespread predilection towards brokerage firms and commercial banks, as well as towards the collection of information at the seller's premises, particularly regarding safe, low- to medium-risk investments, even at the risk of receiving lower profits (Moschis and Nguyen 2008). The differences only emerged when considering the utilitarian motivations behind these products (Moschis et al. 2003): for the "Hermits Indulgers" and the "Healthy Hermits", the convenience represents an added value; for the "Ailing Outgoers", free additional services are more important (e.g. the possibility of managing investments by phone or email), while for "Frail Recluses", this group requires an available staff, just like younger consumers .

Although there are theoretical models that demonstrate the greater benefits deriving from investments in private pension plans compared to government pensions (Collins 
1980), the elderly generally lack knowledge about the financial field; thus, in the absence of targeted awareness campaigns, they cannot sagely associate the benefits and risks. For instance, Duncan et al. (1984) proposed a method for defining the number of resources one would need to accumulate in order to maintain one's previous lifestyle on a pension; this model considers a person's expected retirement age, the level of resources to allocate in investments and private pension funds, and the expected state subsidies. However, the applicability of these models is limited by elderly consumers' widespread inexperience with financial products - which instead leads them to make risky and questionable decisions, such as choosing their investment plans simply on the basis of the largest number of funds therein (Morrin et al. 2008). This inexperience can also involve an inability to properly exploit financial information (Schaub 2003): they may minimize the real risk of the market; anchor their assessments on average rates instead of actual rates; assume that past year returns are objective indicators in any future forecast horizon, and underestimate the risk associated with an investment plan calculated with rates other than the actual ones. Thus, it becomes difficult for the elderly to choose between various pension options.

In the private sector, the Individual Retirement Account (IRA) is proposed as an advantageous individual pension plan, compared to a normal investment with long-term profits, only if advance settlement is not required, given that it does not benefit from long-term profit taxation (Walden 1984); together with the so-called Keogh plan (Keogh is the name of the proposing deputy), which allows self-employed workers to make higher contributions than the IRA, it is typically chosen based on age (advanced) and ethnicity (Caucasian), with maximized income-based contributions (Hira et al. 2009). Alternatively, the defined contribution pension plan called 401( $k$ ) (from the related subsection of the US tax code) allows consumers to set up a fund of social security contributions by deducting amounts directly from the paycheck and taxing them upon retirement: this method has grown in popularity among employees who stay with a company for a long time (Cismaru and Gelb 2005). Alternatively, consumers may address the financial market where preferences do not appear very different, considering the age (Salisbury 1986): 55 to 64 years, which covers a period of relative wealth for mature consumers where income, savings, and possessions reach their peak; and over 65 . Both groups opt for financial instruments that minimize prudent risks and investments (such as preference shares, bond funds, treasury bills, and short-term debt instruments). Although elderly financial planning is naturally geared towards maintaining a high life quality during old age, keeping income unchanged-compared to the working period-and using investments plan only in case of perceived need, for marketers in financial and credit institutions, marketing strategies to implement are not totally clear to marketers (Belonax et al. 1991; Johnson 2008). Javalgi et al. (1991) divided the market of financial instruments by segmenting the elderly into the two aforementioned groups-between 55 and 64 years (Older) and over 65 years (Elderly). The authors found significant differences in terms of discriminating criteria in the choice of, and importance attributed to, the specific characteristics of the financial instruments considered. Consequently, consultants should alter the marketing mix to match the two segments' differing needs. Regarding the service, the older segment prefers speediness, while the elderly seek personalized assistance; regarding the convenience of the location, older workers emphasize longer opening hours, while the elderly seek proximity to their home; regarding communication, older consumers gravitate towards products' liquidity, while the elderly emphasize the safety of funds; as far as prices are concerned, older consumers prefer lower loan rates, while the elderly prefer higher interest on savings. In terms of pricing policies, Javalgi et al. (2000) suggested that younger seniors generally appreciate unrelated products and services, each with its own specific price; meanwhile, the elderly prefer a free initial consultation and overall packages at unique prices. Overall, it seems that both groups can be effectively reached by offering supporting activities (i.e. help completing documents) and courteous service (Kennett et al. 1995). On the contrary, financial advisors sometimes implement predatory lending practices, such as in the case of the subprime mortgage market (loans granted to subjects with low ability to meet their obligations), which involved aggressive (and arguably illegal) marketing campaigns (Hill and Kozup 2007) that created the impression of courtesy and speed while providing meagre clarity (Friendly Veneer); they little consider consumers' doubts and requests, promising liquidity in a short time just to engage them (Rules of engagement); after receiving the money, consumers discover the unfavourable conditions of the loan, obtaining poor assistance from creditors and often a worsening of the debt conditions (Aggressive response). Due to the deprivation of essential information, the induction to assume the debt, the use of intrusive and opaque practices, and ultimately the victimization of consumers, the market collapsed and had devastating effects on the world economy.

\section{Legacy management}

\section{Special possessions}

Elderly consumers' financial choices are sensitive not only to economic evaluations (i.e. economic convenience) but also to emotional components, to specific needs of their families (e.g. sons' need for financial help) and to the specific 
moment of life in which such decisions are made (typically when life expectancy is low). Such factors lead the elderly consumers to re-evaluate their financial resources and to plan different allocation of investments and possessions. After a lifetime of accumulating assets, individuals often seek to find physical or legal beneficiaries of their material and spiritual legacy. Some of these assets are considered special possessions: objects with high affective value, treasured regardless of their market value and imbued with historical identity (Folkman Curasi et al. 2004). These inalienable assets are kept and handed down for generations, with family members acting as guardians of these relics. Studying distinct samples in the US and Niger, Wallendorf and Arnould (1988) found that these inheritances are related to the significant memories of individuals' lives and serve to strengthen people's identities. Research has shown that people feel increasing attachment to such assets as they age and may view new purchases as superfluous. The reason goes beyond mere utilitarianism: By evoking experiences and emotions, these inheritances symbolically grant a sense of "immortality" (Gentry et al. 1995). When an elderly person decides to donate a special asset to a loved one, this process involves different methods and transfer practices than a typical gift exchange (Ekerdt et al. 2012; Folkman Curasi et al. 1998; Gentry et al. 1995; Sherry et al. 1992). In such cases, elderly owners draw on their cultural identity, family uses, and relationships (Price et al. 2000) in order to imbue the object with their "aura" - the latent messages that persist across time and must be decoded by younger beneficiaries.

\section{Charities}

Elderly people are usually more generous towards needy people and organizations that express their solidarity through donations, inheritance bequests, or philanthropic and social entrepreneurial initiatives. The economic, sociological and marketing fields have proposed many theories to explain why people decide to donate. According to Sargeant (1999), six elements drive individuals to donate: external inputs, such as requests for help, appeals, facts, images; extrinsic determinants, such as age, sex, income, social status, geodemographic factors; intrinsic determinants, such as the need for self-esteem, guilt, compassion, sense of social justice, empathy, fear, sympathy; the so-called perceptual reactions, which concern the type of representations, resistance to external stimuli, self-acceptance, interference; and processing determinants, such as past experiences and judgment criteria, which interact to produce specific outputs (in terms of the size of the donation, loyalty, money, courtesy, time dedicated to others). According to other studies (Mathur 1996), elderly donations to charitable organizations are mainly due to social motivations, such as the expectation of acknowledgments, human interactions for the gift bestowed, or displays of control over the outside world. Recent contributions also suggest an interesting relationship between age and pro-social behaviour (Kettner and Waichman 2016; Pornpattananangkul et al. 2019). Considering the exponential growth of the non-profit sector and the saturation of fund requests, it is essential, on the one hand to stimulate the least inclined segments (young people) to donate and, on the other hand, to encourage the elderly.

An important funding tool for charities is legacies: a fundraising method that involves developing long-lasting relationships with donors (Magson and Routley 2009). According to Wiepking et al. (2010), although the literature suggests that attitudes (related to values) and structures (related to the donor's characteristics) drive the decision to leave one's inheritance to charity, the only factor to find empirical support so far is the belief in the effectiveness of non-profit associations' activities. Indeed, research has found that various antecedents-such as altruistic, political or religious values, and the degree of wealth-have no strong relationship to charitable giving. New modern forms of charity, which could be successfully used to cover the growing costs of medical research, are the Venture Philanthropy Initiatives and Social Entrepreneurship (Scaife 2008), differing from classical philanthropy due to the high commitment of the philanthropist (investor/donor) in the management of funding, both in terms of time (long-term perspective) and willingness to directly support those who are lowest in the socio-economic context.

\section{Rites of passage}

When the end of life approaches, elderly consumers must deal with the rites of passage between generations in order to preserve their own identity over time. Heisley (1997) performed three empirical studies on the intergenerational transfer of wealth, that is, the use of inheritances to create shared family meanings. The flow of wealth from parents to sons (money, property or other goods) constitutes a cultural form through which familial, ethnic and socioeconomic values are communicated and preserved. From a phenomenological perspective, the act of bequeathing one's valuables to loved ones is a symbolic way of distributing parts of oneself. Granted, the generations who lived through the Great Depression era may have felt a greater need to leave an inheritance to loved ones than the elderly of the Baby Boom, probably because the inheritance was used to improve the living conditions of their sons. According to White Riley (1973), each generation faces a unique context and an unrepeatable sequence of events: techniques such as Cohort Analyses could help to understand the phenomenon of ageing and the succession of generations. In managing the relationship with death, elderly individuals develop a 
series of motivational mechanisms that turn into consumption behaviours. Ignoring extreme cases (such as palliative care wherein decisions are remitted to doctors according to ethical criteria) (Coustasse et al. 2008), there are at least five major latent desires for consumers who feel close to passing away (beyond the conservation of one's assets). Urien and Guiot (2007) highlighted some commercial strategies aimed at satisfying these desires: preserving physical integrity in order to delay death (e.g. through the consumption of healthy food products capable of preventing the onset of cancers); maintaining relationships with family and friends to feel part of a group (using software to facilitate the use of email, video calls, social networks, etc.); increasing self-esteem to rebuild one's identity (using websites to find descendants from famous people); satisfying one's religious sentiment (accessing sacred texts and prayer communities); and prolonging life after death (exploiting medical, genetic or cryogenic science). While practitioners must be sensitive to the moral and deontological risks of profaning a sacred theme like death, providing comfort to those close to passing represents a new frontier for marketing strategies (Fan and Zick 2004). When individuals are near death, they are driven by a strong desire to preserve their own identity (Folkman Curasi et al. 1998), which can take the form of donations. According to Guillemot and Urien (2010), there are six main reasons why those close to death donate meaning-infused objects, such as autobiographical (or legacy) writings: praise for one's own successes, therapy for one's ego, desire to be remembered, desire for sharing, desire for transmission, and the willingness to transfer one's testimonies. Basically, the elderly want to donate not only their heritage, but also the stories and symbolic values attached to the objects that comprise their heritage (Folkman Curasi et al. 2003). Thus, administrators and financial advisors who monitor assets should strengthen their trust relationships with elderly consumers' heirs. It is also useful for managers to understand the concept of the "extended self", appreciating the sense of immortality nestled in material inheritance. According to Belk (1990), the concept of "extended self"-wherein individuals' identity can transcend the physical body to symbolically occupy objects in their environment-could be enlarged from space to time. In other words, individuals' identity could be understood through the stories and events they connect to certain things (photos, souvenirs, trophies, etc.). However, even when elderly do not materially transfer heirlooms, the existence of the birthplace or other objects could contribute to create a sense of immortality: their past is thus nestled in the material inheritance able to reveal the related mysteries to their being and passage on this earth. By appreciating the sense of immortality nestled in material inheritance, managers may be able to propose financial services aimed at preserving such special possessions guaranteeing the correct succession practice and custody.

\section{Conclusion}

This paper sought to critically review and discuss elderly financial choices. We examined academic articles published in marketing and consumer publications across a five-decade span (1970-2019), focusing on Financial Asset Management and Inheritance. Firstly, the results show that the attitudes of older people can influence their decision process (and by extension, their heritage) and financial dispositions. Older consumers today are more educated, physically active, and invested in socio-cultural activities; thus, they represent the ideal target for new and personalized financial products. Secondly, they have ample purchasing power and information access, and are thus becoming more aware of and informed in their choices. Despite the impressive growth of the elderly population and its formidable market power, few companies understand this segment and its peculiarities (McKinsey 2016). Thus, marketers should reconsider this ignored slice of consumers, identifying their propensities and characteristics in order to design customized services that satisfy their economic and emotional expectations. For investors who already considered these demographic changes in their portfolio decisions, some of our conclusions are self-evident. In the coming decades, older people will exercise a greater influence on consumption patterns due to their growing numbers and wealth. Consequently, financial companies need to adapt their emerging offers to the attitudes, values, and behaviours of the elderly. In doing so, firms need to be sensitive to important decisions about special possessions (which represent priceless embodiments of identity) and general legacies (which seek to preserve an individual's desired self-image, e.g. through philanthropic and social entrepreneurial initiatives).

Naturally, our study features some limitations. First, while we did uncover consistent insights across different cultural backgrounds, it is possible that the reviewed studies overlooked some cultural differences. Second, the considered time period involved significant social changes, which meaningfully influenced elderly lives. Therefore, further studies could widen the research framework by considering specific historical contingencies or cultural contexts. Moreover future studies could focus on the role of elderly active ageing and their cognitive abilities (see Strough et al. 2020), together with behavioural aspects and older consumers' characteristics such as personality or other individual differences.

Funding Open access funding provided by Università del Salento within the CRUI-CARE Agreement.. Open access funding provided by Università del Salento within the CRUI-CARE Agreement.. The authors received no financial support for the research, authorship, and/ or publication of this article. 


\section{Compliance with ethical standards}

Conflict of interest The authors declare no potential conflicts of interest with respect to the research, authorship, and/or publication of this article.

Open Access This article is licensed under a Creative Commons Attribution 4.0 International License, which permits use, sharing, adaptation, distribution and reproduction in any medium or format, as long as you give appropriate credit to the original author(s) and the source, provide a link to the Creative Commons licence, and indicate if changes were made. The images or other third party material in this article are included in the article's Creative Commons licence, unless indicated otherwise in a credit line to the material. If material is not included in the article's Creative Commons licence and your intended use is not permitted by statutory regulation or exceeds the permitted use, you will need to obtain permission directly from the copyright holder. To view a copy of this licence, visit http://creativecommons.org/licenses/by/4.0/.

\section{References}

Asebedo, S.D., M.C. Seay, K. Archuleta, and G. Brase. 2019a. The psychological predictors of older preretirees' financial self-efficacy. Journal of Behavioral Finance 20(2): 127-138.

Asebedo, S.D., M.J. Wilmarth, M.C. Seay, K. Archuleta, G.L. Brase, and M. MacDonald. 2019b. Personality and saving behavior among older adults. Journal of Consumer Affairs 53(2): 488-519.

Bal, F., and P. Nijkamp. 2001. In search of valid results in a complex economic environment: The potential of meta-analysis and value transfer. European Journal of Operational Research 128(2): 364 384. https://doi.org/10.1016/S0377-2217(00)00078-3.

Barusch, A. 2013. The aging tsunami: Time for a new metaphor? Journal of Gerontological Social Work 56(3): 181-184.

Bateman, H., J. Louviere, S. Thorp, T. Islam, and S. Satchell. 2010. Investment decisions for retirement savings. Journal of Consumer Affairs 44(3): 463-482.

Bearden, W.O., and R.P. Wilder. 2007. Household life-cycle effects on consumer wealth and well-being for the recently retired. Journal of Macromarketing 27(4): 389-403.

Belk, R.W. 1990. The role of possessions in constructing and maintaining a sense of past. ACR North American Advances in Consumer Research 17: 669-676.

Belonax Jr., J.J., R.G. Javalgi, S.R. Rao, and E.G. Thomas. 1991. Marketing of financial services to the elderly in the retail banking industry: Strategic guidelines. Journal of Professional Services Marketing 6(2): 157-176.

Brennan, C., and E. Ritch. 2010. Capturing the voice of older consumers in relation to financial products and services. International Journal of Consumer Studies 34(2): 212-218.

Chevalier, C. 2003. The stakes in the over $50 \mathrm{~s}$ market for financial institutions in France. Journal of Financial Services Marketing 8(2): 145-151.

Cismaru, M., and B. Gelb. 2005. Antecedents of Abrand Loyalty@ in 401 (K) Plans As Clues to Purchase Criteria For Retirement Investments. ACR Asia-Pacific Advances in Consumer Research 6: $52-55$

Collins, R.A. 1980. Estimating the benefits of individual retirement accounts: a simulation approach. Journal of Consumer Affairs 14(1): 124-141.

Coughlin, J.F., and L.A. D'ambrosio. 2009. Seven myths of financial planning and baby boomer retirement. Journal of Financial Services Marketing 14(1): 83-91.
Coustasse, A., T. Quiroz, and S.G. Lurie. 2008. To the bitter end: Disparities in end-of-life care. Journal of Hospital Marketing \& Public Relations 18(2): 167-185.

Devaney, S.A., and S. Hanna. 1994. The effect of marital status, income, age and other variables on insolvency in the USA. Journal of Consumer Studies \& Home Economics 18(3): 293-303.

Duncan, G.J., O.S. Mitchell, and J.N. Morgan. 1984. A framework for setting retirement savings goals. Journal of Consumer Affairs 18(1): 22-46.

Dunne, J., and D. Turley. 1997. Banking schemes for seniors-Bonus or unwelcome badge? Irish Marketing Review 10(1): 27.

Ekerdt, D.J., M. Luborsky, and C. Lysack. 2012. Safe passage of goods and self during residential relocation in later life. Ageing \& Society 32(5): $833-850$.

Fan, J.X., and C.D. Zick. 2004. The economic burden of health care, funeral, and burial expenditures at the end of life. Journal of Consumer Affairs 38(1): 35-55.

Ferguson, R., and B. Brohaugh. 2010. The aging of Aquarius. Journal of Consumer Marketing 27(1): 76-81.

Folkman Curasi, C., L.L. Price, and E.J. Arnould. 1998. A meaning transfer model of the disposition decisions of older consumers. ACR European Advances in Consumer Research 3: 211-221.

Folkman Curasi, C.F., L.L. Price, and E.J. Arnould. 2003. Understanding the intergenerational transmission of cherished possessions: Insights for estate planning, trust officers and other end-of-life professionals. Journal of Financial Services Marketing 7(4): 369-383.

Folkman Curasi, C.F., L.L. Price, and E.J. Arnould. 2004. How individuals' cherished possessions become families' inalienable wealth. Journal of Consumer Research 31(3): 609-622.

Gamble, K.J., P.A. Boyle, L. Yu, and D.A. Bennett. 2015. Aging and financial decision making. Management Science 61(11): $2603-2610$

Gentry, J.W., S.M. Baker, and F.B. Kraft. 1995. The role of possessions in creating, maintaining, and preserving one's identity: Variation over the life course. ACR NA Advances in Consumer Research 22: 413-418.

Goldstein, D.G., E.J. Johnson, and W.F. Sharpe. 2008. Choosing outcomes versus choosing products: Consumer-focused retirement investment advice. Journal of Consumer Research 35(3): $440-456$.

Gough, O., and P.D. Sozou. 2005. Pensions and retirement savings: cluster analysis of consumer behaviour and attitudes. International Journal of Bank Marketing 23(7): 558-570.

Grace, D., S. Weaven, and M. Ross. 2010. Consumer retirement planning: An exploratory study of gender differences. Qualitative Market Research: An International Journal 13(2): 174-188.

Guido, G. 2006. Il comportamento di consumo degli anziani: Una rassegna sistematica (1970-2005) [The consumer behaviour of the elderly: A systematic review]. Mercati \& Competitività 1: 53-82.

Guillemot, S., and B. Urien. 2010. La rédaction d'une histoire de vie chez les personnes âgées: fondements conceptuels, dimensionnement et proposition d'une échelle de mesure des motivations au récit de vie. Recherche et Applications en Marketing (French Edition) 25(4): 25-43.

Hauff, J.C. 2014. Trust and risk-taking in a pension investment setting. The International Journal of Bank Marketing 32(5): 408-428.

Heisley, D.D. 1997. The Intergenerational Flow of Wealth in the Family. Advances in Consumer Research 24(1): 242-243.

Hemmasi, M., W.C. Lesch, and L.A. Graf. 1992. Determinants of investment strategies in the trust-fund market: An empirical study of self-directed retirement account holders. Journal of Professional Services Marketing 8(1): 165-176. 
Hill, R.P., and J.C. Kozup. 2007. Consumer experiences with predatory lending practices. Journal of Consumer Affairs 41(1): 29-46.

Hira, T.K. 1997. Financial attitudes, beliefs and behaviours: Differences by age. Journal of Consumer Studies \& Home Economics 21(3): 271-290.

Hira, T.K., W.L. Rock, and C. Loibl. 2009. Determinants of retirement planning behaviour and differences by age. International Journal of Consumer Studies 33(3): 293-301.

Hogarth, J.M. 1987. Work after retirement: Intentions, realities and implications. Journal of Consumer Studies \& Home Economics 11(3): 207-218.

Javalgi, R.G., J.J. Belonax Jr., and A.M. Robinson. 1991. Mature consumers in the financial services marketplace-potential market segments. Journal of Professional Services Marketing 6(1): 81-107.

Javalgi, R.G., E.G. Thomas, and S.R. Rao. 2000. Meeting the needs of the elderly in the financial services marketplace: an empirical analysis. Journal of Professional Services Marketing 20(2): $87-105$.

Johnson, M. 2008. Quality of life aspirations: Exploring baby-boomer financial means-end goal structures. Journal of Financial Services Marketing 13(3): 245-258.

Kennett, P.A., G.P. Moschis, and D.N. Bellenger. 1995. Marketing financial services to mature consumers. Journal of Services Marketing 9(2): 62-72.

Kettner, S.E., and I. Waichman. 2016. Old age and prosocial behavior: Social preferences or experimental confounds? Journal of Economic Psychology 53: 118-130.

Kim, H., and A.C. Lyons. 2008. No pain, no strain: Impact of health on the financial security of older Americans. Journal of Consumer Affairs 42(1): 9-36.

Lee, H.S. 1994. Factors influencing financial strain on elderly people who live alone in the USA. Journal of Consumer Studies \& Home Economics 18(3): 265-278.

Lee, J.M., J. Lee, and K.T. Kim. 2019. Consumer financial well-being: Knowledge is not enough. Journal of Family and Economic Issues 25: $1-11$.

Lindbergh, J., R.A. Nahum, and S. Sandgren. 2008. Population ageing: opportunities and challenges for retail banking. International Journal of Bank Marketing 26(1): 6-24.

Lusardi, A., and O. S. Mitchell. 2011. Financial literacy and planning: Implications for retirement wellbeing (No. w17078). National Bureau of Economic Research.

Magson, N., and C. Routley. 2009. Using data in legacy fundraising: A practical approach. International Journal of Nonprofit and Voluntary Sector Marketing 14(4): 333-340.

Masud, J., S.A. Haron, and L.W. Gikonyo. 2008. Gender differences in income sources of the elderly in Peninsular Malaysia. Journal of Family and Economic Issues 29(4): 623-633.

Mather, M., P. Scommegna, and L. Kilduff. 2019. Fact sheet: Aging in the United States. Population Reference Bureau, 15 July 2019. https://www.prb.org/aging-unitedstates-fact-sheet/.

Mathur, A. 1996. Older adults' motivations for gift giving to charitable organizations: An exchange theory perspective. Psychology \& Marketing 13(1): 107-123.

McKinsey. 2016. Getting to know urban elderly consumers. Retrieved at: https://www.mckinsey.com/industries/consumer-packagedgoods/our-insights/getting-to-know-urban-elderly-consumers Accessed on the 12th January, 2020.

Morrin, M., S. Broniarczyk, J.J. Inman, and J. Broussard. 2008. Saving for retirement: The effects of fund assortment size and investor knowledge on asset allocation strategies. Journal of Consumer Affairs 42(2): 206-222.

Moschis, G.P. 1996. Gerontographics: Life-stage segmentation for marketing strategy development. Westport: Greenwood Publishing Group.
Moschis, G., D. Bellenger, and C.F. Curasi. 2003. Financial service preferences and patronage motives of older consumers. Journal of Financial Services Marketing 7(4): 331-340.

Moschis, G.P., and J.N. Burkhalter. 2007. Making ends meet: How will the elderly manage their finances and post-retirement expenses? Journal of Financial Services Marketing 12(3): 235-241.

Moschis, G.P., and H.V. Nguyen. 2008. Affluent mature consumers: Preference and patronisation for financial services. Journal of Financial Services Marketing 13(3): 259-267.

Mullis, R.J., and E.J. Metzen. 1986. Age and wealth: a cross/withincohort analysis. Journal of Consumer Studies \& Home Economics 10(3): 221-234.

Oehler, A., and C. Werner. 2008. Saving for retirement-a case for financial education in Germany and UK? An economic perspective. Journal of Consumer Policy 31(3): 253-283.

Phillips, C.R., D.K. Schuler, and E.W. Jacobs. 1994. Inequality in health insurance reform: Are the elderly more. Marketing Health Services 14(4): 14.

Philp, P.R., P.J. Haynes, and M.M. Helms. 1992. Financial service strategies: neglected niches. International Journal of Bank Marketing 10: 25-28.

Pornpattananangkul, N., A. Chowdhury, L. Feng, and R. Yu. 2019. Social discounting in the elderly: Senior citizens are good Samaritans to strangers. The Journals of Gerontology: Series B 74(1): $52-58$.

Price, L.L., E.J. Arnould, and C. Folkman Curasi. 2000. Older consumers' disposition of special possessions. Journal of Consumer Research 27(2): 179-201.

Rickwood, C., and L. White. 2009. Pre-purchase decision-making for a complex service: retirement planning. Journal of Services Marketing 23(3): 145-153.

Riley, M.W. 1973. Aging and cohort succession: Interpretations and misinterpretations. Public Opinion Quarterly 37(1): 35-49.

Salisbury, P.A. 1986. Old money: Senior markets for financial services. Journal of Professional Services Marketing 2(1-2): 75-79.

Sargeant, A. 1999. Charitable giving: Towards a model of donor behaviour. Journal of marketing management 15(4): 215-238.

Scaife, W. 2008. Venturing into venture philanthropy: Is more sustainable health and medical research funding possible through venture philanthropy and social entrepreneurship? Journal of Nonprofit \& Public Sector Marketing 20(2): 245-260.

Schaub, M. 2003. Stock market timing effects on individual retirement plans: All holding period returns are not 'average'. Journal of Financial Services Marketing 7(3): 267-274.

Sharpe, D.L., J.X. Fan, and G.S. Hong. 2001. Household out-of-pocket health care expenditure trends: 1980-95. International Journal of Consumer Studies 25(2): 114-122.

Sherry, J.F., M.A. McGrath, and S.J. Levy. 1992. The disposition of the gift and many unhappy returns. Journal of Retailing 68(1): 40-65.

Strough, J., J. Wilson, and W. B. de Bruin 2020. Aging and financial decision making. In Psychological Perspectives on Financial Decision Making (pp. 167-186). Cham: Springer.

The Pew Charitable Trusts. 2015. The Complex Story of American Debt. Retrieved at: https://www.pewtrusts.org/ /media/asset s/2015/07/reach-of-debt-report_artfinal.pdf Accessed on the 25th August, 2020.

Tynan, A.C., and J.L. Drayton. 1988. The neglect of the older consumer. Journal of Consumer Studies \& Home Economics 12(2): 159-171.

Urien, B., and D. Guiot 2007. Attitude face à la mort et comportant d'ajustement des consommateurs ages: vers l'élaboration d'une réponse marketing. Décisions Marketing 23-35.

Walden, M.L. 1984. Estimating the Benefits of Individual Retirement Accounts: A Comparison to Capital Gains Investments. Journal of Consumer Affairs 18(2): 296-303. 
Wallendorf, M., and E.J. Arnould. 1988. "My favorite things": A crosscultural inquiry into object attachment, possessiveness, and social linkage. Journal of Consumer Research 14(4): 531-547.

Weinswig, D. 2016. Global retail trends for 2016. Fung Business Intelligence Centre (FBIC). https://jda.com/-/media/jda/knowledgecenter/ebooks/16-global-retailtrends-for-2016-ebook.ashx.

Wiener, J., and T. Doescher. 2008. A framework for promoting retirement savings. Journal of Consumer Affairs 42(2): 137-164.

Wiepking, P., K. Madden, and K. McDonald. 2010. Leaving a legacy: Bequest giving in Australia. Australasian Marketing Journal (AMJ) 18(1): 15-22.

Xiao, J.J., C. Chen, and L. Sun. 2015. Age differences in consumer financial capability. International Journal of Consumer Studies 39(4): 387-395.

Publisher's Note Springer Nature remains neutral with regard to jurisdictional claims in published maps and institutional affiliations.

Gianluigi Guido (Ph.D., University of Cambridge, UK) is Full Professor of Marketing at the University of Salento, Italy. He has been professor at the University of Padua, Sapienza and LUISS University of Rome, Italy, and visiting researcher at the University of Florida at Gainesville, and Stanford University, USA. He has published 20 books and more than 250 articles in major scholarly journals in the field of marketing and consumer behaviour.

Cesare Amatulli is Associate Professor of Marketing at the University of Bari, Italy. He has been Adjunct Professor at the LUISS University, Rome (Italy), at the EMC Business School, Paris (France), and at the International University of Monaco (Principality of Monaco). He has been Visiting Researcher at the Ross School of Business (USA) and at the University of Hertfordshire (UK). His research focuses on luxury consumption, luxury tourism and sustainability. He has published several articles in major academic journals such as the Journal of Consumer Research, International Journal of Research in Marketing, Journal of Business Ethics, Journal of Business Research.

Andrea Sestino is Ph.D. Candidate in Management and Marketing, at University of Bari (Italy), and Assistant Researcher at University of Salento, Lecce (Italy); he holds a Master's degree in Business Management at Sapienza University, Rome (Italy). Additionally, he is also R\&D Specialist for an Italian consulting company in the field of Applied Research to Digital Business, involved in private and national research projects. His research interests fall in the areas of Business Innovation and Digital Transformation, studying essential components, challenges and opportunities of digital and technology as a phenomenon, and related impact to companies and consumers in designing marketing strategies. 